\title{
PERBEDAAN PENGARUH PENERAPAN STRATEGI KONTRAK KOMPETENSI DAN KEMAMPUAN KONSEP DASAR LISRIK TERHADAP KOMPETENSI MAHASISWA PADA MATA KULIAH PENGANTAR ELEKTRO TEKNIK
}

\author{
Baharuddin \\ baharuddin.bah@gmail.com
}

\begin{abstract}
Abstrak
Penelitian ini bertujuan untuk mengetahui: (1) perbedaan kompetensi mahasiswa dalam Pengantar Elektro Teknik antara kelompok yang diberi pembelajaran dalam bentuk kontrak kompetensi dengan kelompok yang diberi pembelajaran ekspositori, (2) perbedaan kompetensi mahasiswa dalam perkuliahan Pengantar Elektro Teknik antara kelompok yang memiliki kemampuan konsepdasar listrik tinggi dengan kelompok yang memiliki kemampuan konsep dasar listrik rendah, dan (3) adanya interakasi antara kemampuan konsep dasar listrik dengan strategi pembelajaran dalam mempengaruhi kompetensi mahasiswa pada Pengantar Elektro Teknik.

Penelitian ini di lakukan di Jurusan Pendidikan Teknik Elektro, FT Unimed. Metode yang digunakan adalah eksperimen dengan rancangan factorial $2 \times 2$. Jumlah sampel penelitian sebayak 52 orang yang tersebar dua kelas perlakuan. Perlakuan yang diberikan adalah pembelajaran dalam bentuk kontrak kompetensi di suatau kelas, dan pembelajaran ekspositori pada kelas yang lainnya. Data diperoleh dengan melakukan uji kompetensi terhadap mahasiswa setelah perlakuan pembelajaran diberikan. Analisis data yang digunakan adalah teknik analisis varian dua jalur.

Hasil penelitian menunjukkan bahwa: (1) Strategi pembelajaran dalam bentuk kontrak kompetensi memberikan kompetensi mahasiswa yang lebih baik bila dibandingkan dengan strategi pembelajaran ekspositori pada perkuliahan Pengantar Elektro Teknik, hal ini terlihat dari nilai kompetensi rata-rata yang diperoleh siswa pada kelompok yang diajar dengan pembelajaran dalam bentuk kontrak kompetensi mencapai 77,90, sedangkan kelompok siswa yang diajar dengan pembelajaran ekspositori hanya mencapai 69,60. (2) Kelompok mahasiswa yang memiliki kemampuan konsep dasar listrik tinggi memperoleh nilai kompetensi yan lebih baik bila dibandingkan dengan kelompok mahasiswa yang memiliki kemampuan konsep dasar listrik rendah hal ini terlihat dari nilai kompetensi rata-rata yang diperoleh mahasiswa pada kelompok yang memiliki kemampuan konsep dasar listrik tinggi memcapai 76,5, sedangkan kelompok mahasiswa yang memiliki kemampuan konsep dasar listrik rendah hanya mencapai 70,9. (3) Terjadi interaksi antara strategi pembelajaran dengan kemampuan konsep dasar listrik dalam mempengaruhi kompetensi mahasiswa pada perkuliahan Pengantar Elektro Teknik dimana $\mathrm{Fh}=24,47$ dengan probabilitas 0,000 , berarti Ho gagal diterima.
\end{abstract}

\section{Kata Kunci: Strategi, Kompetensi, Dasar kelistrikan}

\section{Pendahuluan}

Dewasa ini sangat sering terdengar bahwa kemampuan sumber daya manusia khususnya lulusan sekolah menengah kejuruan sangat rendah. Ada kecendrungan rata-rata hasil ujian menurun dari tahun sebelumnya maka langsung dituding gurulah penyebabnya. Para guru tidak dapat mengelak dari tudingan tersebut, karena menurunnya hasil belajar tidak terlepas dari perlakuan guru di dalam kelas (sekolah). Ada dugaan yang palingkuat bahwa kelemahan itu terjadi karena guru tidak mampu mengajar dengan baik dan guru belum mampu menalarkan ilmu pengetahuan yang dimiliki kepada siswanya, sehingga menghasilkan siswa yang kurang memiliki daya nalar dalam pola berpikirnya.

Tudingan seperti itu bukan berarti didiamkan saja, perlu dilakukan intrspeksi diri sebelum menkaji permasalahan orang lain, karena 
secara langsung atau tidak permasalahan tersebut ada keterkaitan dengan lembaga penghasil tenaga guru, yaitu Lembaga Penghasil Tenaga Keguruan (LPTK). Satu LPTK yang ada, di antaranya adalah Jurusan Pendidikan Teknik Elektro FT Unimed. Mahasiswa yang sedang belajar di lembaga pendidikan tersebut memiliki daya nalar yang masih rendah dalam setiap pembelajaran.

Pendapat tersebut dapat saja diterima sepanjang tidak dilakukan inovasi pendidikan di Jurusan Pendidikan Teknik Elektro. Artinya, jurusan pendidikan teknik elektro yang merupakan lembaga pendidikan penghasil tenaga guru kejuruan bidang teknik tidak mengembangkan cara atau pola pemahaman konsep-konsep yang sesuai, yaitu dengan mengembangkan keterampilan proses berpikir dalam setiap aktivitas perkuliahan.

Selain itu, berdasarkan hasil pengamatan beberapa orang dosen, tampaknya mahasiswa FT Unimed, hususnya Jurusan Pendidikan Teknik Elektro memiliki kemampuan nalar yang rendah dalam perkulihan. Hal ini, dapat dilihat dari tidak mampunya mahasiswa memberi jawaban yang baik dan terarah pada saat diajukan pertanyaan-pertanyaan yang menuntut kemmapuan berpikir tinggi.

Oleh karena itu, perlu ada upaya peningkatan kualitas mahasiswa, terutama dalam upaya menhasilkan lulusan yang berkualitas dan mampu beradaptasi dengan perkembangan IPTEK. Untuk itu, aktivitas pembelajaran di
Jurusan Pendidikan Teknik Elektro perlu ditingkatkan, karena pembelajaran yang baik diduga akan dapat menumbuhkan sikap kritis mahasiswa dalam menanggapi berbagai permasalahan. Maka dengan itu cara-cara baru yang dilakukan dalam bidang pendidikan dan pengembangan pengalaman belajar perlu untuk terus dikembangkan melalui upaya penyediaan sarana pendidikan, metode pengajaran yang relevan serta strategi pembelajaran yang lebih tepat.

Menurut Norton (1985) hasil terbaik dari suatu pendidikan dengan sifat terkini dan temporer adalah selalu mengacu dan mengantisipasi secara cepat berbagai perubahan baik kebutuhan maupun persyaratan kerja. Oleh karena itu penerapan kurikulum yang dikenal sebagai kurikulum yang berbasis kompetensi, belum cukup membantu memecahkan masalah pendidikan jika tidak dibarengi dengan factorfaktor dominan yang terkait dengan system pembelajaran yang dilakukan di kelas. Berdasarkan kenyataan ini menunjukkan bahwa untuk meningkatkan kompetensi mahasiswa memerlukan penanganan yang sungguh-sungguh agar dapat menghasilkan lulusan yang layak kerja sesuai bidang keahliannya. Salah satu alternative yang dipandang dapat meningkatkan kemampuan mahasiswa dalam menjalankan tugas-tugasnya adalah melalui penerapan pembelajaran yang efektif dan efisien, agar kompetensi yang dimiliki lulusan merupakan kompetensi yang sesuai dengan tuntutan lapangan kerja. 
Salah satu faktor yang cukup dominan mempengaruhi kemampuan mahasiswa dalam memcapai kompetensi yang diharapkan adalah strategi pembelajaran yang diterapkan oleh dosen berdasarkan materi dan karakteristik mahasiswa. Menurut Kemp, Morrison, dan Roos (2003) bahwa salah satu cara untuk meningkatkan keefektifan pemelajaran adalah memiliki atau menetapkan strategi pemelajaran yang sesuai dengan kondisi pemelajaran, seperti karakteristik peserta didik dan tipe isi pemelejaran yang akan yang akan disampaikan, yang kesemuanya diprediksi dapat mempengaruhi hasil belajar, agar dapat memudahkan peserta didik belajar.

Sejalan dengan hal tersebut, Merril (1983) mengemukakan kondisi pemelajaran yang harus dijadikan pijakan dalam menetapkan strategi pemelajaran adalah karakteristik peserta didik dan tipe isi pemelajaran yang akan dipelajari. Dengan demikian agar kemampuan mahasiswa dapat sesuai dengan tujuan pemelajaran yang ditetapkan, maka strategi pemelajaran perlu dikembangkan sesuai dengan isi pembelajaran dan karakteristik peserta didik yang akan dihadapi, atau dengan kata lain bahwa pembelajaran akan efektif bila strategi pembelajaran yang digunakan semakin sesuai dengan karakteristik peserta didik yang diajar dan tipe isi pembelajaran yang disampaikan.

Strategi pembelajaran merupakan gambaran komponen materi dan prosedur atau cara yang digunakan untuk memudahkan mahasiswa belajar. Berdasar kenyataan ini, sebagai tenaga pengajar sangat perlu adanaya variasi strategi pembelajaran yang dirahkan sesuai dengan karakteristik peserta didik dan isi pembelajaran yang disampaikan agar tujuan pembelajaran dapat dicapai sesuai denag yang diharapkan. Menurut Reigeluth (1983) bahwa diantara ketiga variabel pemelajaran, yaitu variabel kondisi pemelajaran, variabel metode pembelajaran, dan variabel hasil pembelajaran, yang berpeluang untuk dimanipulasi hanya variabel strategi pemelajaran, karena variabel strategi pemelajaranlah yang harus disesuaikan dengan kondisi pembelajaran agar strategi efektif untuk meningkatkan hasil pemelajaran.

Untuk menciptakan suasana agar mahasiswa lebih aktif belajar diperlukan kemauan dan kemampuan dosen dalam mengambil keputusan yang tepat dengan situasi belajar yang diciptakan dan mempertimbangkan kondisi pemelajaran yang diprediksi dapat mempengaruhi hasil belajar. Kemauan dan kemampuan dosen untuk menciptakan suatu strategi yang akan diterapkan, sangat perlu dukungan suatu studi yang berkaitan dengan strategi beserta isi pembelajaran yang diasuh.

Faktor lain yang juga sangat menentukan adalah bahwa mahasiswa melaksanakan suatu kegiatan pembelajaran tanpa dibekali dengan pengetahuan awal tentang materi dan proses pelaksanaan pembelajaran, sehingga sering terjadi mahasiswa mereka-reka apa yang dilakukan, dan bahkan tidak dapat memahami isi materi pelajaran yang dipelajari dalam 
kegiatan pembelajaran. Oleh karena itu strategi pemelajaran perlu menjadi perhatian oleh dosen dengan menyadari bahwa pola berfikir formal yang hipotetik deduktif diperlukan mahasiswa untuk menstrukturisasi kembali pengetahuan yang dimilikinya untuk mendapatkan pengertian terhadap objek yang baru. Salah satu strategi yang dipandang sesuai dengan karakteristik tersebut adalah strategi kontrak kompetensi, dimana strategi ini sangat relevan dengan kurikulum kompetensi, serta memberikan peluang kepada mahasiswa agar lebih aktif, kretif, dan pembelajaran lebih efektif dan menyenangkan. Strategi ini merupakan konsep belajar yang membantu dosen mengaitkan antara materi yang diajarkan dengan situasi dunia nyata mahasiswa dan mendorong mahasiswa membuat hubungan antara pengetahuan yang dimilikinya dengan penerapannya dalam kehidupan mereka sebagai anggota keluarga dan masyarakat. Dengan konsep ini, hasil pembelajaran diharapkan lebih bermakna bagi mahasiswa. Dalam kontek itu, mahasiswa perlu mengerti apa makna belajar, apa manfaatnya, dalam status apa mereka, dan bagaimana mencapainya. Tugas dosen mengelola kelas sebagai sebuah tim yang bekerja sama untuk menemukan sesuatu yang baru bagi mahasiswa. Sesuatu yang berupa pengetahuan dan keterampilan datang dari upayah menemukan sendiri, bukan dari apa kata dosen. Begitulah peran dosen di kelas yang dikelola dengan strategi kontrak kompetensi.
Penerapan strategi kontrak kompetensi adalah mengemas suatu kompetensi dalam bentuk kontrak antara mahasiswa dengan dosen, sehingga mahasiswa harus terlibat langsung dengan sub-sub kontrak kompetensi yang harus dikerjakan sehingga tercapainya kompetensi yang diinginkan.

\section{Berdasarkan latar belakang masalah permasalahan dalam ini dirumuskan:}

1. Apakah terdapat perbedaan kompetensi mahasiswa pada perkuliahan Pengantar Elektro Teknik antara kelompok yang diberi pemelajaran dalam bentuk kontrak kompetensi dengan kelompok yang diberi pemelajaran ekpositori?

2. Apakah terdapat perbedaan kompetensi mahasiswa pada perkuliahan Pengantar Elektro Teknik antara kelompok yang memiliki kemampuan dasar kelistrikan tinggi dengan kelompok mahasiswa yang memiliki kemampuan kelistrikan rendah?

3. Apakah terdapat interaksi antara kemampuan konsep dasar listrik dengan strategi pemelajaran pada perkulihan Pengantar Elektro Teknik mahasiswa?

\section{Kompetensi Pengantar Elektro Teknik}

Secara etimologis kompetensi berasal dari bahasa Ingeris yaitu competence yang atrinya well-qualified atau capabily. Dalam bahasa 
Indonesia diterjemahkan menjadi berkulifikasi atau mempunyai kulifikasi atau mampu atau mempunyai kemampuan (Webster, 2003). Kompetensi juga diarikan sebagai skill atau keahlian. Kemudian Salim (1997) menebutkan competen berarti properly or well qualified, having legalcapacity or qualified to testify artinya bahwa kualifikasi yang baik dan memadai atau kemampuan yang resmi dan legal, diakui dan siap untuk dibuktkan secara terus menerus. Sedangkan Depdiknas (2003) menefinisikan kompetensi sebagai pengetahuan, keterampilan, dan nilai-nilai dasar yang direfleksikan dalam kebiasaan berpikir dan bertindak. Blank (1982) mengartikan sebagai kemampuan untuk melakukan sesuatu bukannya kemampuan yang lebih tradisional untuk mendemonstrasikan pengetahuan.

Sedangkan Keputusan Mendiknas No.045/U/2002 tentang kurikulum inti Pendidikan Tinggi, kompetensi didefinisikan sebagai seperangkat tindakan cerdas, penuh tanggung jawab yang dimiliki seseorang sebagai syarat untuk dianggap mampu oleh masyarakat dalam melaksanakan tugas-tugas dalam bidang pekerjaan tertentu. Keputusan Mendiknas tersebut dikenal sebagai elemen kompetensi, yang terdiri dari: (1) landasan kepribadian, (2) penguasaan ilmu dan keterampilan, (3) kemampuan berkarya, (4) sikap dan prilaku dalam berkarya menurut tingkat keahlian berdasarkan ilmu dan keterampilan yang dikuasai, serta (5) pemahaman kaidah kehidupan bermasyarakat sesuai dengan pilihan keahlian dalam berkarya.

Gatot (2002) dalam mengembangkan kompetensi, mahasiswa harus dilatih pula untuk cerdas mengembangkan sikapnya. Sikap mahasiswa yang positif akan memaknai kompetensi yang dimilikinya. Dengan demikian, kompetensi yang utuh tersebut merupakan terapan dari pengetahuan, pemahaman dan keterampilan yang dibingkai oleh sikap dan nilai yang mengutamakan kemaslahatan peserta didik yang dilayani. Kompetensi akan menggambarkan kemampuan kerja lulusan suatu program pendidikan.

Berdasarkan paparan di atas, maka yang dimaksud kompetensi mahasiswa pada Pengantar Elektro Teknik adalah hasil penilaian atas kemampuan kerja mahasiswa pada tingkat memuaskan, yaitu perilaku kerja yang berkemampuan untuk mentransfer dan mengaplikasikan keterampilan-keterampilan dan pengetahuan dalam melakukan perawatan dan perbaikan system Elektro Teknik berdasarkan standar kompetensi yang tertuang dalam standar kompetensi sebagai bagian dari kurikulum kompetensi.

\section{Strategi Pembelajaran}

Anglin (1991) mengemukakan bahwa pembelajaran adalah cara pengorganisasian dan pengaturan informasi bagi mahasiswa 
yang meliputi sejumlah elemen-elemen utama seperti penyampaian informasi, pemberian contoh-contoh, praktek dan umpan balik. Gagne dan Briggs (1979) berpendapat bahwa pembelajaran adalah suatu perangkat peristiwa yang mempengaruhi mahasiswa sedemikian rupa sehingga terjadi proses belajar.Finch dan Crunkilton (1979) pembelajaran adalah interaksi antara dosen dengan mahasiswa untuk mencapai hasil yang diharapkan. Dengan demikian pembelajaran diartikan sebagai pola pengaturan dan penentuan materi belajar agar mahasiswa dapat memcapai tujuan belajar dengan efektif dan efisien. Haney dan Ullmer (1980) berpendapat bahwa selama pembelajaran berlangsung dosen dapat menggunakan beberapa jenis peristiwa untuk meningkatkan pembelajaran, yaitu: meningkatkan motivasi mahasiswa, menetapkan secara jelas tujuan yang akan dicapai, pembelajaran berorientasi pada mahasiswa, menunjukkan stimulus yang diperlukan pada waktu belajar, memberikan beberapa cara untuk menyatukan partisipasi belajar mahasiswa, dan memberikan unpan balik bagi mahasiswa yang benar pekerjaannya. Sehubungan dengan peristiwa belajar ini, Gagne dan Briggs (1979) lebih lanjut mengemukakan bahwa proses belajar dapat dipengaruhi melalui peristiwa-peristiwa pembelajaran yang sifatnya eksternal,yaitu: menarik perhatian mahasiswa, mengemukakan pra syarat pelajaran yang perlu diketahui,mempresentasikan materi stimulus, menyediakan bimbingan belajar, menunjukkan kemampuan yang akan dicapai, memmerikan umpan balik terhadap hasil belajar yang benar, menilai prestasi belajar, dan meningkatkan ingatan (retensi) dan pengalihan (transfer). Pada dasarnya semua kegiatan yang berkaitan dengan pemelajaran dimaksudkan untuk mencapai tujuan yang di harapkan.

\section{Strategi Pemelajaran Kontrak Kompetensi}

Pemelajaran dapat diartikan sebagai pola pengaturan dan penentuan serangkaian peristiwa yang mempengaruhi mahasiswa sedemikian rupa sehingga terjadi proses belajar mengajar. Pemelajaran dalam bentuk kontrak kompetensi merupakan konsep pemelajaran yang membantu dosen agar mahasiswa berperan secara aktif dalam kegiatan pemelajaran, dan peran aktif ini sangat diharapkan dapat membantu masiswa untuk menemukan dan mengalami sejumlah pengalaman-pengalaman baru yang terkait dengan materi pembelajaran. Hamidin (2001) bahwa konsep pemelajaran kontekstual adalah peroses pambelajaran yang merangkumkan contoh yang dibuat dari pengalaman harian dalam kehidupan pribadi masyarakat serta profesi dan menyajikan aplikasi hands-on yang konkrit tentang bahan yang akan dipelajari. Choy (1999) bahwa pembelajaran dan kurikulum yang sesuai dengan pemelajaran konteks sebaiknya melaksanakan dan melakukan lima aspek yang menjadi asas 
pelaksanaan pemelajaran konteks yaitu: (1) relate,yaitu menghubungkan atau mengaitkan pengalaman harian dengan konsep yang dipelajari, (2) experience yakni mengalami kejadian atau fenomena itu sendiri secaran langsung atau terus menerus, (3) apply yaitu mengaplikasikan konsep yang dipelajari dalam kehidupan seharian dan dalam konteks kerja/profesinya, (4) cooperative yaitu penuasaan ilmu melalui aktivitas dan pengalaman bekerja bersama denga orang lain,dan (5) transfer yaitu memindahkan ilmu yang berkaitan dan sesuai dengan kompetensi yang diperlukan ,serta kritis dan kreatif.

Secara garis besar komponen penting yang diperlukan pada kegiatan pemelajaran dalam bentuk kontrak kompetensi antara lain:

a. Memahami Tujuan atau Kompetensi yang akan dicapai

b. Menyusun Rencana Kegiatan yang dilakukan oleh Mahasiswa

c. Penemuan dalam Pelaksanaan Kontrak Kompetensi

d. Bekerja Sama untuk Mencapai Tujuan

e. Interaksi Sosial Melalui Kegiatan TanyaJawab

f. Refleksi dan Pengayaan

\section{Strategi Pemelajaran Ekspositori}

Pada hakekatnya pengajaran dikelas dapat di rancang dengan baik untuk mencapai tujuan pengajaran. Dalam pelaksaannya pengajaran Ekspositori kegiatan pemelajaran lebih terpusat pada dosen, dan dosen menyampaikan materi pelajaran sesuai dengan rancangannya dan orientasi pengajaran seluruhnya tertuju pada dosen.Dalam pengajaran ini di harapkan perhatian mahasiswa secara penuh diarahkan pada uraian atau penjelasan materi pelajaran yang diuraikan dosen.

Pengajaran ini memberi kesan yang kurang menekankan keaktifan mahasiswa dalam belajar,karena sifat pengajarannya berorientasi kepada dosen. Selain itu,dengan menerapkan strategi pengajaran ini kurang memberikan keluasaan bagi mahasiswa dalam mengikuti pelajaran sesuai dengan kemampuan yang dimiliki (Joice dan Weil,2004).

Pengajaran terpusat pada dosen ini juga di anggap sebagai pengajaran Ekspositori, dimana pengajaran berpedoman pada intruksi dosen dan laju belajar mahasiswa ditentukan oleh dosen.Mahasiswa beralih ke topik atau tugas yang lain secara bersama-sama dengan mahasiswa lain yang ada dalam satu kelas (ruangan).Pendekatan yang digunakan adalah pendekatan komunikatif namun pada dasarnya mengutamakan pendekatan audio-lingual dengan buku pegangan atau buku yang telah ditetapkan oleh dosen.

Ada beberapa kelemahan yang di temukan pada disain pengajaran Ekspositori, yaitu: potensi mahasiswa yang memiliki kemampuan belajar yang baik tidak dapat terwujud sebagaimana mestinya karena laju belajarnya 
terhambat, penyajian materi dan khirarhinya kurang terencana secara spesifik.

\section{Kemampuan Konsep Dasar Listrik}

Konsep merupakan dasar berpikir untuk belajar aturan-aturan, dan akhirnya untuk memecahkan masalah. Dahar (1991) mengemukakan konsep merupakan dasar bagi proses-proses mental yang lebih tinggi untuk merumuskan prinsip-prinsip dan generalisasigeneralisasi maupun untuk memecahkan masalah. Selanjutnya Ausubel (1968) menyatakan bahwa konsep adalah abstrak dari benda-benda, kejadian-kejadian, situasi-situasi atau cirri-ciri khas dan terwakili dalam setiap budaya oleh suatu tanda atau simbol. Rosser $\&$ Nicholson (1984) menjelaskan pengertian konsep adalah suatu abstraksi yang mewakili satu kelas objek, kejadian-kejadian,kegiatankegiatan, atau hubungan-hubungan yang mempunyai atribut yang sama.

Untuk memasuki suatu pembelajaran, mahasiswa tidaklah berangkat dari nol, melainkan suatu kelanjutan dari proses pemelajaran yang telah berlangsung sebelumnya. Dick dan Carey (2005) bahwa kemampuan awal (entry behavior) adalah keterampilan spesifik (skill) yang harus dapat di demonstrasikan oleh mahasiswa yang memasuki suatu aktifitas pemelajaran. Dengan demikian mahasiswa yang mengikuti pelajaran dasar kelistrikan juga harus memiliki pemahaman tertentu yang dapat menunjang kemampuan tersebut yang telah diperoleh sebelumnya.

Mempelajari konsep dasar listrik adalah sama dengan mengkaji konsep-konsep dasar yang berkenaan dengan sistem kelistrikan yang meliputi: besaran dan satuan listrik, sumber listrik, listrik magnet, penghantar arus listrik, bahan konduktor, isolator, semi konduktor, komponen aktif,dan komponen aktif dalam rangkaian.

\section{Metode Penelitian}

\section{Tempat dan waktu penelitian}

Penelitian ini dilakukan pada Jurusan Pendidikan Teknik Elektro FT Unimed pelaksanaan penelitian dilakukan pada semester genap 2013 waktu penelitan selama empat bulan sampai selesai laporan penelitian

\section{Populasi dan Sampel}

Dalam tulisan ini,yang menjadi populasi adalah mahasiswa Jurusan Pendidikan Teknik Elektro. Sampel di tetapkan dengan teknik purposive sampling,jumlah sampel lima puluh dua orang responden yang di bagi dalam dua kelas atau kelompok. Setiap kelompok terdiri dari 13 responden.

\section{Variabel penelitian}

Dalam penelitian ini dilibatkan varibel bebas yakni strategi pemelajaran terdiri dari pemelajaran kontrak kompetensi dan pemelajaran Ekspositori,sedangkan pemahaman konsep dasar listrik dibagi atas 
dua kelompok pemahaman konsep dasar listrik tinggi dan pemahaman konsep listrik rendah. Sedangkan variabel terikat adalah kompetensi mahasiswa pada perkuliahan Pengantar

\section{Rancangan penelitian}

Elektro Teknik berupa hasil penilaian kompetensi berdasarkan standar kompetensi yang ditetapkan dalam kurikulum

Tabel penelitian disain faktorial $2 \times 2$

\begin{tabular}{|c|c|c|c|}
\hline \multirow{2}{*}{} & \multicolumn{2}{c|}{ Strategi Pemelajaran } \\
\cline { 3 - 4 } \multicolumn{2}{|c|}{ Variabel } & Kontrak Kompetensi & Ekspositori \\
\hline $\begin{array}{c}\text { Kemampuan } \\
\text { Konsep Dasar } \\
\text { listrik }\end{array}$ & Tinggi & P1 & P3 \\
\cline { 2 - 4 } & Rendah & & P4 \\
\hline
\end{tabular}

Keterangan:

P1 = Kompetensi kelompok mahasiswa yang di berikan perlakuan strategi kontrak kompetensi yang

memiliki pemahaman konsep dasar listrik tinggi.

P2 = Kompetensi kelompok mahasiswa yang di berikan perlakuan strategi kontrak kompetensi yang

memiliki pemahaman konsep dasar listrik rendah.

P3 = Kompetensi kelompok mahasiswa yang di berikan perlakuan strategi Ekspositori yang memiliki

pemahaman konsep dasar listrik tinggi.

P4 = Kompetensi kelompok mahasiswa yang di berikan perlakuan strategi Ekspositori yang memiliki

pemahaman konsep dasar listrik rendah

Analisis data yang digunakan untuk pengujian hipotesis serta pangaruh antar variabel adalah analisis varians (ANOVA) $2 \times 2$. Sebelum pengujian hipotesis dilaksanakan, terlebih dahulu dilakukan uji persyaratan analisis, serta sebelum diadakan pengujian-pengujian, data terlebih dahulu dideskripsikan. Dalam deskripsi data dilaporkan tentang maen, standar deviasi, nilai maksimum dan minimum.

Untuk uji persyaratan analisis dilakukan pengujian normalitas untuk semua veriabel dengan menggunakan uji statistik Lilliefors melalui SPSS. Kriteria yang digunakan adalah data distribusi normal jika signifiknsi lebih besar 0,05. Selain uji normalitas dilakukan juga uji homogenitas variabel dilakukan dengan uji Lavene's dengan bantuan SPSS. Homogen atau tidaknya ditentukan oleh 
besarnya uji signifikansi yang di berikan. Kriteria data memiliki varians yang homogen jika perbandingan antara nilai signifikan hitung menunjukkan nilai lebih besar dari 0,05 .

Setelah pengujian persyaratan analisis maka dilanjutkan pengujian hipotesis dengan teknik analisis variansi untuk tiap variabel beserta interaksinya. Untuk pengujian hipotesis dilakukan pada taraf signifikansi $5 \%$.

\section{Hasil Penelitian dan pembahasan}

\section{Hasil Penelitian}

Dari hasil penelitian diperoleh 52 data berupa hasil penelitian terhadap kompetensi mahasiswa pada Pengantar Elektro Teknik. Data tersebut diperoleh dari sampel penelitian yang terbesar dalam dua kelas perlakuan dengan perincian 26 data yang di peroleh dari kelas pemelajaran dalam bentuk kontrak kompetensi dan 26 data di peroleh dari kelas pembelajaran dengan menggunakan pemelajaran Ekspositori. Masing-masing kelas perlakuan terbagi lagi ke dalam dua kelompok yaitu kelompok yang memiliki kemampuan konsep dasar listrik tinggi dan kemampuan konsep dasar listrik rendah.

Secara keseluruhan data penellitan atas komptensi mahasiswa pada Pengantar Elektro Teknik menunjukkan rata-rata 73,75 dengan standar deviasi 10,188 . Nilai tertinggi yang diperoleh mahasiswa adalah 95,00, sedangkan nilai terendah adalah 50,00. Secara terperinci deskrip data dari masing-masing kelompok eksperimen ditunjukkan sebagai berikut:

Tabel 2. Rangkuman Deskripsi Data

\begin{tabular}{|l|l|l|l|l|}
\hline \multicolumn{1}{|c|}{ Strategi } & \multicolumn{1}{|c|}{ K.awal } & \multicolumn{1}{c|}{ Meam } & \multicolumn{1}{c|}{ Standar deviasi } & \multicolumn{1}{c|}{ N } \\
\hline \multirow{5}{*}{ K.Kompetensi } & Rendah & 70.0000 & 6.1237 & 13 \\
\cline { 2 - 5 } & Tiggi & 85.7692 & 6.0712 & 13 \\
\cline { 2 - 5 } & Total & 77.90 & 10.0173 & 26 \\
\hline \multirow{5}{*}{ Ekspositori } & Rendah & 71.9231 & 7.2280 & 13 \\
\cline { 2 - 6 } & Tinggi & 67.3077 & 9.7073 & 13 \\
\cline { 2 - 6 } & Total & 69.60 & 8.7090 & 26 \\
\hline & Rendah & 70.96 & 6.6361 & 26 \\
\cline { 2 - 6 } & Tinggi & 76.54 & 12.3101 & 26 \\
\cline { 2 - 6 } & Total & 73.7500 & 10.1882 & 52 \\
\hline
\end{tabular}




\section{Pengujian Hipotesi}

Pengujian hipotesis dilakukan dengan menggunakan analisis varian (ANAVA). Hasil perhitungan yang diperoleh dari bantuan SPSS dituhjukkan pada table 3 .

Tabel 3.Rangkuman Hasil Perhitungan ANAVA

\begin{tabular}{|l|c|l|r|r|l|}
\hline Source & \multicolumn{1}{|l|}{$\begin{array}{l}\text { Type III Sum of } \\
\text { Squares }\end{array}$} & df & Mean Squars & F & Sig. \\
\hline Corrected Model & 2643.750 & 3 & 881.250 & 15.962 & .000 \\
\hline Intercept & 282831.3 & 1 & 282831.3 & 5122.981 & .000 \\
\hline Strategi & 888.942 & 1 & 888.942 & 16.102 & .000 \\
\hline K.Awal & 404.327 & 1 & 404.327 & 7.324 & .009 \\
\hline Stategi*K.Awal & 1350.481 & 1 & 1350.481 & 24.462 & .000 \\
\hline Error & 2650.000 & 48 & 55.208 & & \\
\hline Total & 288125.0 & 52 & & & \\
\hline Corrcted Total & 5293.750 & & & & \\
\hline
\end{tabular}

a. R Squared $=.499$ (Adjusted R Squared $=.468)$

Dari hasil perhitungan dengan tabel ANVA seperti pada tabel 3 diperoleh Fhitung =16,102 dengan nilai probabilitas atau taraf signifikan 0,000, hal ini berarti bahwa hipotesis nol (Ho) ditolak, atau hipotesis alternatif $(\mathrm{Ha})$ diterima. Dengan demikian terdapat perbedaan yang signifikan dari kedua kelompok eksperimen, dalam arti bahwa kompetensi mahasiswa yang diberi pemelajaran dalam kontrak kompetensi berbeda dengan komptensi mahasiswa yang diberikan pemelajaran Ekspositori

Dari hasil perhitungan dengan tabel ANAVA seperti pada tabel 3 diperoleh Fhitung=7,324 dengan nilai probabilitas 0,009 , hal ini berarti bahwa hipotesis nol (Ho) ditolak, atau hipotesis alternatif (Ha) diterima. Dengan demikian terdapat perbedaan yang signifikan dari kedua kelompok eksperimen, dalam arti bahwa kompetensi mahasiswa yang memiliki kemampuan konsep dasar listrik tinggi berbeda dengan kompetensi mahasiswa yang memiliki kemampuan konsep dasar listrik rendah.

Dari hasil perhitungan dengan tabel ANAVA seperti pada tabel 3 diperoleh Fhitung=24,462 dengan nilai probabilitas 0,000 , hal ini berarti bahwa hipotesis nol (Ho) gagal diterima, berarti terdapat interaksi antara strategi 
pembelajaran dengan kemampuan konsep dasar listrik, dalam arti bahwa terjadi interaksi antara strategi pembelajaran dengan kemampuan konsep dasar listrik dalam mempengaruhi kompetensi mahasiswa pada perkuliahan Pengantar Elektro Teknik

\section{Pembahasan}

Keunggulan dari pembelajaran dalam bentuk kontrak kompetensi yang dipapakarkan pada konsep teori terbukti secara empiris dilapangan sehingga hasil temuan ini menguatkan bahwa dengan pembelajaran dalam bentuk kontrak kompetensi,kompetensi mahasiswa akan lebih baik. Keunggulan lain dari pembelajaran bentuk kontrak kompetensi yang ditemukan dilapangan adalah bahwa rataKemampuan konsep dasar listrik sangat berpengaruh terhadap peningkatan kompetensi mahasiswa pada perkuliahan Pengantar Elektro Teknik. Hal ini tebukti dari hasil temuan yang menguatkan bahwa mahasiswa yang memiliki kemampuan dan penguasaan konsep dasar listrik yang tinggi lebih menguasai suasana pembelajaran, lebih aktif dalam kelas, dan lebih dominan dalam situasi tanya jawab. Sedangkan bagi mahasiswa yang kurang menguasai konsep dasar listrik cenderung lebih pasif, dan kelihatan ragu-ragu dalam memberikan pendapat dan bahkan cenderung terlambat atau ketinggalan dalam memahami isi materi yang diajarkan. Berdasarkan hasil penelitian yang diperoleh memberikan gambaran bahwa dalam proses pembelajaran Pengantar Elektro Teknik sangat rata mahasiswa yang belajar di Jurusan Pendidikan Teknik Elektro lebih tertarik untuk mempelajari keterampilan bila dibandingkan dengan belajar teori atau konsep semata,sehingga umumnya mahasiswa lebih menyenangi bila proses pembelajaran langsung dihadapkan dengan benda yang akan dipelajari dibandingkan dengan diminta untuk membaca bahan atau konsep yang terkait dengan materi yang akan di pelajari. Berdasarkan kenyataan ini menyebabkan pembelajaran dengan menggunakan strategi ekspositori kurang menghasilkan perhatian yang maksimal bagi mahasiswa, oleh Karena mereka kurang tertarik untuk membaca, akibatnya adalah mahasiswa kurang memperoleh informasi yang diperlukan

perlu untuk memperhatikan kemampuan konsepdasar listrik yang dimiliki mahasiswa.

Bedasarkan hasil penelitan memberikan gambaran bahwa rata-rata kompetensi mahasiswa yang di berikan pembelajaran dalam bentuk kontrak kompetensi memang menunjukkan kecendrungan untuk memperoleh kompetensi yang tinggi bagi mahasiswa yang berkemampuan konsep dasar listrik tinggi,sedangakan bagi mahasiswa yang memperoleh pembelajaran Ekspositori menunjukkan perubahan peningkatan kompetensi yang tidak begitu signifikan antara kelompok yang berkemampuan konsep tinggi dengan yang berkemampuan konsep dasar listrik rendah. 


\section{Kesimpulan}

Dari hasil penelitian dapat disimpulkan:

1. Strategi pembelajaran kontrak kompetensi memberikan kompetensi mahasiswa yang lebih baik bila dibandingkan dengan strategi pembelajaran ekspositori pada perkuliahan pengantar elektro teknik, hal ini terlihat dari nilai kompetensi rata-rata yang diperoleh mahasiswa pada kelompok yang diajar dengan pembelajaran dalam bentuk kontrak kompetensi mencapai 77,90 sedangkan kelompok mahasiswa yang diajar dengan strategi pembelajaran Ekspositori hanya mencapai 69,60.

4. kompetensi mahasiswa pada perkuliahan Pengantar Elektro Teknik, hal ini 5. terbukti dari hasil penelitian yang menunjukkan bahwa bagi kelompok mahasiswa yang memiliki kemampuan konsep dasar listrik tinggi memperoleh nilai kompetensi lebih baik bagi yang dijar dengan pembelajaran dalam bentuk kontrak kompetensi, sedangkan bagi mahasiswa yang memiliki konsep dasar listrik rendah memperoleh nilai kompetensi lebih baik bagi yang diajar dengan strategi Ekspositori.

\section{Daftar Pustaka}

Anglin,G.J(1991).Instructional

Technology:Past, Present, and Future.

Englewood,Colorado:Libraries

Unlimited,Inc
2. Kelompok mahasiswa yang memiliki kemampuan konsep dasar listrik tinggi memperoleh nilai kompetensi yang lebih baik bila dibandingkan dengan kelompok mahasiswa yang memiliki kemampuan konsep dasar listrik rendah,hal ini terlihat dari nilai kompetensi rata-rata yang diperoleh mahasiswa pada kelompok yang memiliki kemampuan konsep dasar listrik tinggi mencapai 76,54, sedangkan kelompok mahasiswa yang memiliki kemampuan konsep dasar listrik rendah hanya mencapai 70,96 .

3. Terdapat interaksi antara strategi pembelajaran dengan kemampuan konsep dasar listrik dalam mempengaruhi

\author{
Blank,W. E.(1982).Handbook for \\ developing competency based training \\ programs.Englewood \\ Cliffs, NJ.:Prentice Hall. \\ Choy, Ng Kim. (1999).Desain \\ pembelajaran
}

Kontekstual,http://www.teachersrock.net

Dahar,R,W,(1991).Teori-teori

belajar,Surabaya,Erlangga.

Dick,W.,dan Carey,L.(2005).The

Systematic design of Instruction. Third

Edition. Harper Collins

Publishers.

Finch,C.R.,

\&Crunkilton,J.R.(1979).Curricul um development in vocational and technical education: 
Planning, content, and implementation.

Boston : Allyn and Company,

Inc.

Gagne, R. M. \& Briggs, L. J.

(1979).Principles of instruction

design. New York: Holt,

Rinehard \& Winston .

Gatot Hari Priowirjanto

(2004).Kompetensi Harus

Seimbang Nilai Moral: Media

Indonesia, 14 Juni 2004

http://www.rajaraja.com/news_de

tail.php?id_news $=752$

Haney, J. B., \& Ullmer,E.J.

(1980).Eductional communication

and technolology : An

introduction.Iowa;Wm.C.brown

Company Publishers.

Joyce, B., \& Weil, M. (2004).Models of teaching. Englewood Cliffs, NJ.:

Prentice Hall.

Kemp, J.E. Morrison, G,R \& Roos, S.M, (2003).Designing efective instruction. New York:

Macmillan Collage Publishing

Company.

Keputusan Mendiknas Nomor

045/U/2002, tentang: kurikulum

inti Pendidikan Tinggi.

Merril, M.D.,(1994). Component Display

Theory. Dalam Regeludh, C.M.,

(Ed).Instructional desing Theories

\& Models : An Overviw of Teir

Current status. Hillsdale, N.J..:

Lawrence Eribaun Assciaties.
Norton , R,E., (1985).Dacum Hanbook,

Columbus , Ohio: The National

Center for Reserarch in

vocational Education, the ohio

state University.

Regeluth , Charles M. (1983).

Instructional desing theory \& models : An overview of their status. Hilsdale. NJ.: Laurence

Erlblaunm Associates

Publishers.Practice. Boston: Little

Brown.

Rosser, R.A. \& G.L., Nicholson. (1984).

Educational Psychology,

Principles in Practice Boston:

Little Brown.

Sudjana.(1989).Disain dan analisis eksperimen.(edisi VI).Bandung: Tarsito.

Surakhmad, W. (1994).Pengantar interaksi mengajar, dasar dan teknik metodologi pemelajaran.Bandung : Tarsito

Perbedaan Pengaruh Penerapan Strategi Kontrak Kompetensi Dan Kemampuan -93 